\title{
Induction or consolidation chemotherapy for unresectable stage III non-small-cell lung cancer patients treated with concurrent chemoradiation: a retrospective study
}

\section{Eş zamanlı kemoradyoterapi uygulanan opere edilemeyen lokal ileri evre küçük hücreli dışı akciğer kanserinde indüksiyon ve konsalidasyon kemoterapisinin yeri: retrospektif çalışma}

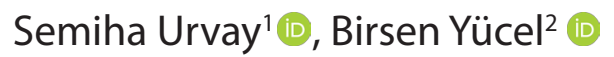

${ }^{1}$ Acıbadem Kayseri Hospital, Department of Medical Oncology, Kayseri/Turkey

${ }^{2}$ Cumhuriyet Universtiy Faculty of Medicine, Department of Radiation Oncology, Sivas/Turkey

\begin{abstract}
Aim: The objective of this study is to demonstrate the efficacy of induction or consolidation chemotherapy on survival in locally advanced non-small cell lung cancer ( NSCLC) patients who were treated by curative concurrent chemoradiotherapy (CCRT).

Material and Methods: Patients were randomised to CCRT, induction chemotherapy followed by CCRT or CCRT followed by consalidation chemotherapy retrospectively. A platinum-based doub-let cytotoxic chemotherapy regimen used as induction/consalidation. Patients who received $60 \mathrm{~Gy}$ or more were included in the study. These patients had received two or more cycles of platinum-based chemotherapy concurrently with definitive radiation therapy.
\end{abstract}

Results: A total of 114 patients were included in the study. 32 (28\%) patients were in CCRT arm; 54 (47\%) patients were in induction arm and 28 (25\%) patients were in consalidation arm.Median overall survival (OS) was found as $21.9 \pm 14.0$ months and 2 year and 3-year survival as \%46 and 33\% in all patients. Median OS did not differ between arms; with a median OS of $29.7 \pm 8.8$ months, $23 \pm 2.9$ months and $16.8 \pm 3.5$ months in the CCRT arm, in the induction arm and in the consolidation arm (p:0.54). The 2 years OS was 53\%, 50\% and 32\% (p:0.48) and 3 years OS was 40\%, 33\% and 25\% ( p:0.40) in the CCRT arm, the induction arm in the consalidation arm without a significiant difference.

Conclusion: In this retrospective study, platin-based chemotherapy as induction or consolidation with concurrent chemoradiotherapy failed to further prolong OS. The standart of care for unresectable stage III NSCLC is still concurrent chemoradiotherapy .

Keywords: non small cell lung cancer; chemoradiotherapy; induction; consalidation

Corresponding author*: Semiha Urvay, Acıbadem Kayseri Hospital, Department of Medical Oncology, Kayseri/Turkey

E-mail: s.elmaci@yahoo.com.tr

ORCID: 0000-0002-0181-3842

Received: 5.10.2018 Accepted : 18.03.2019

Doi: 10.21601/ortadogutipdergisi.467677 


\section{Öz}

Amaç: Bu çalışmanın amacı eşzamanlı kemoradyoterapi ile tedavi edilen küçük hücreli dışı akciğer kanserinde (KHDAK) indüksiyon veya konsalidasyon kemoterapilerinin yalnızca kemoradyoterapi (KRT) ile karşılaştıııldığında sağkalıma etkinliğinin araştırılmasıdır.

Gereç ve Yöntemler: Lokal ileri evre KHDAK tanısı ile eşzamanlı kemoradyoterapi \pm indüksiyon/konsalidasyon tedavisi alan 114 hastanın dosyaları retrospektif olarak incelendi. İndüksiyon veya konsalidasyon tedavisi olarak platin temelli ikili kemoterapi rejimi kullanıldı. 60-66 Gy torasik radyoterapi ile eşzamanlı tek ajan platin( sisplatin veya karboplatin), platin+etoposid veya platin+taksan içeren kemoterapi protokolleri uygulandı. Sonuçlar: Çalışmaya dahil edilen 114 hastanın $32(28 \%)$ 'si KRT; 54 (47\%) 'si indüksiyon ve 28 (25\%)' si konsalidasyon kolundaydı. Tüm hastalar için ortanca sağkalım $21,9 \pm 14.0$ ay; 2 ve 3 yıllık sağkalım oranları ise $\% 46$ ve $\% 33$ olarak bulundu. KRT; indüksiyon ve konsolidasyon kemoterapisi alan hastaların ortanca sağkalımları sırası ile $29,7 \pm 8,8$ ay; $23 \pm 2,9$ ay ve $16,8 \pm 3,5$ ay olarak saptanmış olup anlamlı farklılık yoktu( $p=0,54)$. 2 yıllık sağkalım oranları KRT kolu için $53 \%$; indüksiyon kolu için $50 \%$ ve konsalidasyon kolu için $32 \%$ ( $p=0,48) ; 3$ yıllık sağkalım oranları ise sırası ile $40 \%, 33 \%$ ve $25 \%(p=0,40)$ olarak saptanmış olup benzerdi.

Sonuç: Bu retrospektif çalışmada, eşzamanlı kemoradyoterapiye eklenen indüksiyon veya konsolidasyon kemoterapisinin genel sağkalımı uzatmadığı gösterilmiştir. Rezeke edilemeyen evre III KHDAK için standart tedavi hala eş zamanlı kemoradyoterapidir.

Anahtar kelimeler: küçük hücreli dışı akciğer kanseri; kemoradyoterapi; indüksiyon; konsalidasyon

\section{Giriş \\ Introduction}

Lung cancer is the most common cause of cancer death in the USA and only $17 \%$ of patients have 5 -year or longer survival after diagnosis for all stages.1,2Non small cell lung cancer (NSCLC) is accounted for about $80-85 \%$ of all newly diagnosed lung cancers. 3 Nearly one third of patients with non small cell lung carcinoma (NSCLC) are diagnosed with unresectable stage III disease.4 The standart treatment for the patients with unresectable stage IIIA and IIIB NSCLC is concurrent chemotherapy with thoracic radiation ( CCRT).5-8 Platinum doublet is the backbone of concurrent chemotherapy regimens used with thoracic radiation.6 However, seeking for optimal treatment continues because of the still low levels of survival such as 15-21 months.6-9 The combination of chemotherapy and thoracic radiotherapy often needs a dose reduction of chemotherapy due to increased toxicity. Full dose chemotherapy before (induction chemotherapy) or after ( consalidation chemotherapy)the concurrent chemoradiotherapy may help to eradicate the metastatic diease and provide survival advantage. The benefit of induction and consolidation chemotherapy; and the optimal sequencing between chemoradiotherapy and chemotherapy is still being investigated. Although superiority of induction and consolidation chemotherapies over CRT alone could not be established, consolidation treatment is increasingly used in patients who do not give a good response to CCRT.9,11-13
The objective of this study is to explore both induction and consolidation strategies in locally advanced non small cell lung cancer patients who were treated by curative intent CCRT.

\section{Material and Methods}

This study was designed as a single center retrospective study. Data of the patients administered CCRT \pm induction or consolidation chemotherapy with the diagnosis of inoperable Stage III NSCLC in Cumhuriyet University Medical Faculty between 2007 and 2015 were retrospectively examined. Eligible patients had histologically documented stage III, locally advanced, unresectable NSCLC according to 7th version of American Joint Committee on Cancer (AJJC) TNM classification.

A total of 114 patients were included in the study. One hundred and three (90\%) patients were male and $11(10 \%)$ patients were female with a median age found as 60 (3181) years and Eastern Coo-perative Oncology Group (ECOG) scoring system 0-1.10 Patients were divided into 3 groups accor-ding to the administered treatment. Induction arm: Induction chemotherapy + CRT ; CCRT arm: Concurrent CRT alone; Consolidation arm: CRT + consolidation chemotherapy. Induction or con-salidation chemotherapy regimens were accepted standard treatment combinations of a platinum and a cytotoxic drug (etoposide, gemcitabine or taxane). 32 (28\%) patients were in CCRT arm; 54 (47\%) patients were in induction arm and 28 (25\%) patients were in consalidation arm.

Only patients who received 60 Gy or more were included in the study. These patients had received two or more cycles 
of platinum-based chemotherapy (weekly P ; EP or PT ) concurrently with defi-nitive radiation therapy.

Final status of the patients was accessed from the hospital recordings and through "death notification system" for those without follow-up. Overall survival was calculated as the duration from the date of diagnosis to the last follow-up time for survived patients and to the date of death for died patients.

\section{Ethics statement}

The study was conducted in accordance with the Declaration of Helsinki. The study was approved by Cumhuriyet University Ethics Committee for Non-Interventional Clinical Investigations. Ethics committee decision date: 25.11.2016; no:2016-11/05

\section{Statistical Analysis}

For statistical analyses, firstly the descriptive properties of variables (mean, median, number and percentage) are found. Kruskal Vallis test was used to compare the numerical variables of multiple groups. Categorical data were compared statistically using the chi-square and Fisher's exact test.The survival rates were calculated according to the Kaplan-Meier

Table 1. Patient Demographic and Clinical Characteristics

\begin{tabular}{|c|c|c|c|c|c|c|}
\hline & \multicolumn{2}{|c|}{ CCRT alone } & \multicolumn{2}{|c|}{ Induction+ CCRT } & \multicolumn{2}{|c|}{ CCRT+Consalidation } \\
\hline & No.of Patients & $\%$ & No.of Patients & $\%$ & No.of Patients & $\%$ \\
\hline \multicolumn{7}{|l|}{ Age, years } \\
\hline Median & \multicolumn{2}{|l|}{61} & \multicolumn{2}{|l|}{60} & \multicolumn{2}{|l|}{62} \\
\hline Range & \multicolumn{2}{|c|}{$38-76$} & \multicolumn{2}{|c|}{$40-69$} & \multicolumn{2}{|c|}{$41-73$} \\
\hline \multicolumn{7}{|l|}{ Sex } \\
\hline Male & 29 & 90,60 & 47 & 87 & 27 & 96,40 \\
\hline Female & 3 & 9,40 & 7 & 13 & 1 & 3,60 \\
\hline \multicolumn{7}{|l|}{ Performance status } \\
\hline $0-1$ & 16 & 94,10 & 12 & 100 & 4 & 100,00 \\
\hline $2-3$ & 1 & 5,90 & 0 & 0 & 0 & 0,00 \\
\hline \multicolumn{7}{|l|}{ Comorbidite } \\
\hline No & 20 & 62,50 & 24 & 44,4 & 14 & 50,00 \\
\hline Yes & 12 & 37,50 & 30 & 55,6 & 14 & 50,00 \\
\hline \multicolumn{7}{|l|}{ Pathology } \\
\hline Adenocarcinoma & 7 & 21,90 & 10 & 18,5 & 3 & 10,70 \\
\hline Squamous & 23 & 71,90 & 34 & 63 & 21 & 75,00 \\
\hline NOS & 2 & 6,30 & 10 & 18,5 & 4 & 14,30 \\
\hline \multicolumn{7}{|l|}{ Stage } \\
\hline IIIA & 17 & 53,10 & 29 & 53,7 & 11 & 39,30 \\
\hline IIIB & 15 & 46,90 & 25 & 46,3 & 17 & 60,70 \\
\hline \multicolumn{7}{|l|}{ Nstage } \\
\hline No & 8 & 25,00 & 10 & 18,5 & 5 & 17,90 \\
\hline N1 & 1 & 3,10 & 7 & 13 & 5 & 17,90 \\
\hline $\mathrm{N} 2$ & 23 & 71,90 & 30 & 55,6 & 15 & 53,60 \\
\hline N3 & 0 & 0,00 & 7 & 13 & 3 & 10,70 \\
\hline
\end{tabular}

method. The difference between the treatment groups was compared with the log rank test. Survival rates at 24 and 36 months were examined using life tables.The Statistical Package for Social Sciences (SPSS) for Windows 17.0 (SPSS, Inc., Chicago, IL, USA) was used for the statistical analysis. P values $\leq 0.05$ were accepted as statistically significant.

\section{Results}

\section{Patient Characteristics}

One hundred and three (90\%) patients were male and 11 (10\%) patients were female with a median age found as 60 (31-81) years. In histopathological examination; 78(68\%) patients had squamous cell carcinoma and $20(18 \%)$ patients adenocarcinoma, while histologic subtyping could not be done in 16 (14\%) patients (not otherwise specified - NOS). Fifthy-seven (50\%) patients were at stage IIIA and 57 (50\%) patients at stage IIIB. Fifthy six (49\%) patients had comorbidity ( hypertension, diabetes mellitus or coronary artery disease). No significant difference was found among the treatment arms in terms of gender, age, histopathological type, comorbidity, stage and performance status. The clinical characteristics of the patients are summarized in table 1. 


\section{End Points}

Median overall survival (OS) was found as $21.9 \pm 14.0$ months and 2 year and 3-year survival as $46 \%$ and $33 \%$ in all patients ( Figure 1). Median OS did not differ between the three arms, with a median OS of $29.7 \pm 8.8$ months, $23 \pm 2.9$ months and 16.8 \pm 3.5 months in the CCRT arm, in the induction arm and in the consolidation arm respectively ( Figure 2) (p:0.54). The 2 years and 3 years OS was 53\% -40\% in the CCRT arm, 50\%$33 \%$ in the induction arm and $32-25 \%$ in the consalidation arm without a significiant difference (Table 2). ( $p>0.05$ )

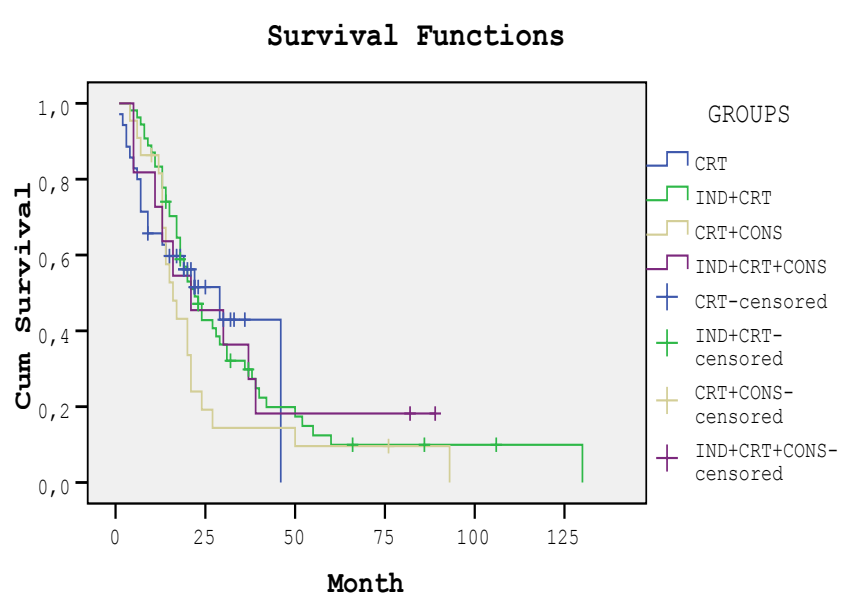

Figure 1.Survival curves of the treatment groups

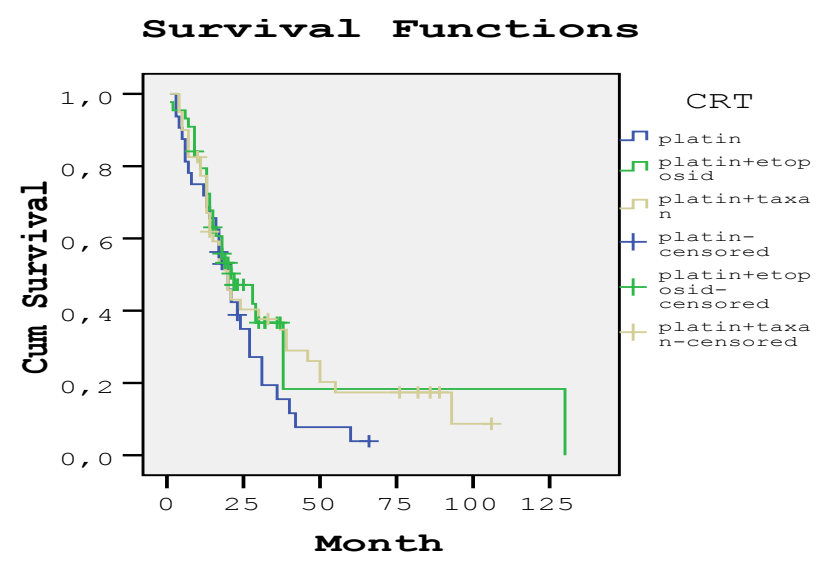

Figure 2. Survival curves according to KRT regimens.

When effect of chemotherapy regimens administered concurrently with radiotherapy on survival was analyzed; there was no statistically significant difference. Median survival was found as 20 months, 22 months and 20 months, while 3-year survival was found as $16 \%, 37 \%$ and $35 \%$ in P, PE and PT arms; respectively ( $\mathrm{p}: 0.310)$.

\begin{tabular}{|c|c|c|c|c|}
\hline Table 2. Survival outcome & $\begin{array}{c}\text { CCRT } \\
\text { alone }\end{array}$ & $\begin{array}{c}\text { Induction+ } \\
\text { CCRT }\end{array}$ & $\begin{array}{c}\text { CCRT+ } \\
\text { Consalidation }\end{array}$ & $\mathrm{p}$ \\
\hline $\begin{array}{c}\text { Median ( } \\
\text { months) }\end{array}$ & 29,7 & 23 & 16,8 & 0,54 \\
\hline $\begin{array}{c}\text { 2-years } \\
\text { survival (\%) }\end{array}$ & 53 & 50 & 32 & 0,48 \\
\hline $\begin{array}{c}\text { 3-years } \\
\text { survival (\%) }\end{array}$ & 40 & 33 & 25 & 0,4 \\
\hline
\end{tabular}

\section{Safety}

Toxicity data of all patients could not be reached due to retrospective design. The records regarding acute toxicity could be reached in 28 patient in CCRT arm, 41 patients in induction arm and 27 patients in consalidation arm.Toxicities throughout the treatment courses were comparable between three arms. No significant differences were observed in grade 3-5 neutropenia, leucopenia, esophagitis, pneumonitis, or treatment-related death. But when we looked at the toxicities seen during chemoradiotherapy; the incidences of Grade 3-5 leukopenia $(p<0.001)$, neutropenia $(p<0.001)$ and thrombocytopenia $(p=0.042)$ were statistically significantly higher in concurent platin+etoposide arm arm compared to the other concurrent treatment regiments.

\section{Dissussion}

The standart therapy for localized and inoperable NSCLC consists of CCRT with a platinum-based doublet and 60-66 Gy of RT delivered daily over 6 weeks.5,6,7,8 Despite its acceptance as a curative intent treatment; median survival rates of only 20 22 months and 5-year overall survival rates of \%15-20. There is an urgent need for new approaches to improve the outcomes of patients. Thus ,the effects of induction / consolidation chemotherapy on survival were investigated in many trials. Most of this studies have been small phase I/II trials, few large randomised phase III trials have been conducted. There have been differences in patient characteristics, chemotherapy regimens used for induction, consalidation or CCRT backbones in these studies; but almost all failed to demonstrate that induction/consolidation chemotherapy provide survival benefit to concurrent chemoradiotherapy.

In a study by Belani et al, the optimal sequencing of paclitaxel/carboplatin with standart thoracic radiotherapy in patients with locally advanced unresectable stage III NSCLC was investigated. In this Phase II trial, 257 patients were 
randomised into three groups. 1) sequencial chemotherapy and radiotherapy group 2)induction chemotherapy followed by concurrent chemoradiotherapy group and 3)concurrent chemoradiotherapy followed by consalidation chemotherapy group. Median survival was slightly higher with consalidation chemotherapy ( 16.3 months), than with the sequential ( 13 months) and induction chemotherapy (12,7 months).11 In another Phase II trial; induction or consalidation chemotherapy with cisplatin/paclitaxel after concurrent chemoradiotherapy with cisplatine/vinorelbine was evaluated in a similar patient group. Median survival was 19,6 months and 16,3 months in induction and consalidation arms retrospectively and the 4-year survival rates was $\% 21$ in the induction arm and \%30 in the consalidation arm, not statistically significiant.12

In a CALGB study, patients with unresectable stage III NSCLC have been randomized to CCRT with weekly carboplatinpaclitaxel arm or consalidation carbo-paclitaxel followed by CCRT arm. Median survival was found as 12 months in CCRT arm and 14 months in induction arm and 2-year overall survival was similar $(p=0.300) .13$ Hanna et al. showed that consalidation docetaxel treatment after platinum-etoposide administered concurrently with CRT is associated with toxicity without increase in survival.9 Another phase III randomised tral, largest reported to date, failed to demonstrate that docetaxel-cisplatin after completing CCRT with the same agents improved survival.14 A meta-analysis of 41 studies evaluating data of 3479 patients that were published in 2013 showed that, consolidation chemotherapy provides no benefit to survival compared with CRT alone. In that meta-analysis, median survival was found as 19 months in the consolidation arm and 17.9 months in the only chemoradiotherapy arm.15 Consalidation chemotherapy group was further divided into two patterns in this meta-analyses. Continuous consalidation chemotherapy which continues treatment with at least one of the agents given in the initial therapy and switch consalidation chemotherapy which switches to a different agent. Similarly, significant survival advantages were not demonstrated in continuous or switch consalidation chemotherapy compared with CCRT. All of this studies concluded that consolidation chemotherapy after CCRT did not have any survival advantage with the use of continouous or switch consalidation chemotherapies.
In our study, we used continouous or switch induction/ consalidation chemotherapy regimens but this is not a dilemma when examined with literature data, as shown in the above studies. Consistently with the literature, we observed that induction or consolidation chemotherapy has not an improving effect on survival. Survival rates were higher in CCRT alone arm although the difference did not reach to statistical significance.

One of the critics may be that our chemotherapy regimens used concurrently with radiotherapy are different and this diversity can affect results. The optimal chemotherapy regimen administered currently with radiation in patients with stage III non-small cell lung cancer (NSCLC) remains unclear. The most common used chemotherapy regimens concurrently with RT have been cisplatin + etoposide (PE), cisplatin+vinorelbine and carboplatin + paclitaxel (PC). Single agent platinum therapy is often used in patients with poor performance status. While several studies have demonstrated superiority of single agent cisplatin concurrently with RT over RT alone,16 effectiveness of carboplatin is controversial.17The only phase III study in the literature comparing $\mathrm{PE}$ and $\mathrm{PC}$ treatments has shown that $\mathrm{PE}$ might be superior to weekly PC in terms of OS.18 However, results of the Veterans Administration Grup retrospective study published in 2015 are not consistent with results of the study mentioned above. When in that study, data of 1842 patients who have received CCRT retrospectively examined, it was seen that overall survival outcomes were similar in PE and PC groups, but rate of morbidity was higher in PE arm.19 In our study, consistently with literature; 3-year overall survival rates and median survival were found to be similar in all these three treatment arms (median survival: 20 months, 22 months and 20 months; respectively and 3-year overall survival rates: 16\%, $37 \%$ and 35\%; respectively).The effectiveness of single-agent carboplatin treatment was also remarkable. So, it can be said that in this study, the difference in chemotherapy regimens used during chemoradiotherapy does not affect the outcome. Onether limitation is this study's retrospective design and insufficient number of patients. Our toxicity evaluations may not be reliable.

\section{Conclusion}

We believe that although its small sample size and retrospective design, the findings of this study are relevant and consistent 
with the literature. CCRT is still the standart treatment and should remain the reference arm in future trials. Regarding the treatment of stage IV NSCLC patients, we have experienced a great advance in the last decade. Molecular characterization of tumors has provided more effective and less toxic targeted treatments in selected patients. In contrast, for LA-NSCLC patients, no significant progress in treatment strategy has been seen.Therefore, it is urgent to seek new treatment options to improve the prognosis of LA-NSCLC patients. Very nearly, at a study presented at ESMO 2017, the anti-programmed death ligand 1 antibody durvalumab showed significantly longer progression-free survival as consolidation therapy in patients with stage III NSCLC who did not have disease progression after platinum-based chemoradiotherapy.20 The median progression-free survival was 16.8 months with durvalumab versus 5.6 months with plasebo. This is the first study showing that immunotherapy works in LA-NSCLC. Further clinical studies are necassary to establish appropriate CCCT regimens, consalidation or induction therapies,as well as other novel treatment strategies, which lead to survival prolongation and increase in the cure rate of LA-NSCLC patients.

\section{Declaration of conflict of interest}

The authors received no financial support for the research and/or authorship of this article. There is no conflict of interest.

\section{References}

1. Siegel RL, Miller KD, Jemal A. Cancer Statics, 2015. CA Cancer J Clin 2015; 65:5-29.

2. Howlader N, Noone AM, Krapcho M et al. SEER Cancer Statistics Review 1975-2012.

3. Wahbah M, Boroumand N, Castro C, El-Zeky F, Eltorky M. Changing trends in the distribution of the histologic types of lung cancer: a review of 4,439 cases. Ann Diagn Pathol 2007;11:89-96.

4. Yang $P$, Allen MS, Aubry MC et al. Clinical features of 5628 primary lung cancer patients: Experience at Mayo Clinic from 1997 to 2003 . Chest $2005 ; 128: 452-62$.

5. O'Rourke $N$, Roqué I Figuls $M$, Farré Bernadó $N$, Macbeth $F$. Concurrent chemoradiotherapy in non-small cell lung cancer. Cochrane Database Syst Rev 2010;16: CD002140.
6. Curran WJ Jr, Paulus R, Langer CJ et al. Sequential vs. concurrent chemoradiation for stage III non-small cell lung cancer: randomised phase III trial RTOG 9410.J Natl Cancer Inst $.2011 ; 103: 1452-60$.

7. FuruseK,FukuokaM,KawaharaMetal.Phaselll study of concurrent versus sequential thoracic radiotherapy in combination with mitomycin,vindesine and cisplatin in unrezectable stage III nonsmall-cell lung cancer. J Clin Oncol.1999;17:2692.

8. Furuse K, Hosoe S, Masuda N. Impact of tumor control on survival in unresectable stage III non-small cell lung cancer (NSCLC) treated with concurrent thoracic radiotherapy and chemotherapy (abstract). Proc Am Soc Clin Oncol 2000.

9. Hanna N, Neubauer M, Yiannoutsos C et al: Phase III study of cisplatin, etoposide, and concurrent chest radiation with or without consolidation docetaxel in patients with inoperable stage III non-small cell lung cancer:The Hoosier Oncology Group and U.S. Oncology. J Clin Oncol. 2008; 26: 5755-60.

10. Oken MM, Creech RH, Tormey DC et al. Toxicity and response criteria of the Eastern Cooperative Oncology Group. Am J Clin Oncol 1982; 5: 649-55.

11. Belani $\mathrm{CP}, \mathrm{Choy} \mathrm{H}$, Bonomi $\mathrm{P}$, et al. Combined chemoradiotherapy regimens of paclitaxel and carboplatin for locally advanced nonsmall-cell lung cancer: a randomized phase II locally advanced multi-modality protocol. J Clin Oncol 2005; 23: 5883.

12. Fournel $P$, Vergnenégre $A$, Robinet $G$ et al. Induction or consolidation chemotherapy for unresectable stage III nonsmall-cell lung cancer patients treated with concurrent chemoradiation: a randomised phase II trial GFPC - IFCT 0201;Eur J Cancer; 2016; 52:181-87

13. Vokes EE, Herndon JE 2nd, Kelly $M J$ et al. Induction chemotherapy followed by chemoradiotherapy compared bt chemoradiotherapy lone for regionally advanced unresectable stahe II Non-small cell lung cancer. Cncer and Leukemia Group B. J Clin Oncol 2007;25:1698

14. Ahn JS, Ahn YC, Kim JH et al. Multinational randomised Phase III trial with or without consalidation chemotherapy using docetaxel and cisplatin after concurrent chemoradiation in inoperable stage III Non-small cell lung cancer: KCSG-LU05-04. J Clin Oncol 2015; 20; 33: 2660-66. 
15. Tsujino K, Kurata T, Yamamato $S$, et al. Is consolidation chemotherapy after concurrent chemo-radiotherapy beneficial for patients with locally advanced non-small cell lung cancer? A pooled analysis of the literature. J Thorac Oncol 2013;8: 1181-89.

16. Blanke C, Anseri R, Mantravadi R et al. Phase III trial of thoracic irridation with or without cisplatin for locally advanced unresectable non-small cell lung cancer: Hoosier Oncology Group protocol. J Clin Oncol 1995;13:1425-29.

17. Atagi S, Kawahara M, Yokoyama A et al; Japan Clinical Oncology Group Lung Cancer Study Group. Thoracic radiotherapy with or without daily low-dose carboplatin in elderly patients with nonsmall-cell lung cancer: a randomised, controlled, phase 3 trial by the Japan Clinical Oncology Group (JCOG0301). Lancet Oncol 2012; 13: 671-78.
18. Liang J, Bi N, Wu S et al. Etoposide and cisplatin versus paclitaxel and carboplatin with concurrent thoracic radiotherapy in unresectable stage III non-small cell lung cancer: a multicenter randomized phase III trial. Ann Oncol 2017; 1: 28: 777-83.

19. Santana-Davila R, Devisetty K, Szabo A et al. Cisplatin and etoposide versus carboplatin and paclitaxel with concurrent radiotherapy for stage III non-small-cell lung cancer: an analysis of Veterans Health Administration data. J Clin Oncol 2015; 33: 567-74.

20. Antonia SJ, Villegas A, Daniel D et al. Durvalumab after Chemoradiotherapy in Stage III Non-Small-Cell Lung Cancer. N Engl J Med 2017; 8. 